\title{
PAVOL PLESNÍK
}

\section{ČO JE VYSOKÉ POHORIE?}

\begin{abstract}
P. Plesník: The term "high mountains". - Sborník ČGS, 97, 1, p. 33-45 (1992). - This contribution deals with different opinions of what should be considered "high mountains". The author tries to assess the value of individual high-mountains phenomena for the differentiation of high-mountains landscape from others types. The existing misleading terminological shortage - as he suggests - could be eliminated by substituting the adjective "high mountains" by "cold" ("cold landscape", and if it is prevaling in some mountains, then "cold mountains").
\end{abstract}

KEY WORDS: geomorphological terminology - high mountains.

Názory na problém, čo považovat za vysoké pohorie, nie sú jednotné. V literatúre sa ukazujú zhruba dva pohlady a $z$ nich vyplývajúce aj odlišné kritériá pre roztriedenie na vysoké a ostatné pohoria. Autori hesiel sovietskej geografickej encyklorédie (Geografičeskij enciklopedičeskij slovar, 4) považujú za dôležité ,,principium divisionis" pre rozdelenie vysokých a ostatných pohorí absolútnu a relatívnu výšku pohoria ako aj reliéf. Naproti tomu C. Troll (12 a inde) používa celkom iné diferenciačné kritériá. Pokúsime sa rozobrat stanoviská spomenutých rozdielnych pohladov a zaujat vlastný postoj. Ide nám o posúdenie názorov na vysoké pohoria $\mathrm{z}$ hladiska krajinných typov, typických krajinných znakov, teda v zmysle doterajších predstáv o vysokých pohoriach v literatúre.

\section{Vysoké pohoria podla výšky a príp. reliéfu}

Podla spomenutej sovietskej encyklopédie (4) pohoria sú rozdelené do troch kategórií: vysoké (obyčajne nad 2000-3000 m), stredne vysoké (obyčejne poniže $3000 \mathrm{~m}$ ) a nízke (ich absolútna výška neprevyšuje $1000 \mathrm{~m}$ ). Vysoké pohoria sú uvedené $\mathrm{v}$ jednom hesle $\mathrm{s}$ vysokohorským reliéfom, $\mathrm{v}$ titule hesla sú oddelené len čiarkou (,,vysokohorský reliéf, vysoké pohorie“) a odlíšené inou hrúbkou písma. Obdobné je to aj $u$ hesiel dalších dvoch spomenutých kategórií pohorí. $\mathrm{Z}$ tejto formy vyplýva, že texty v heslách se vztahujú aj na kategórie pohorí.

Vysokohorský reliéf (a aj vysoké pohorie) predstavuje (podla uvedeného prameňa) typ horského reliéfu, ktorý sa vyznačuje velkou vertikálnou členitostcu ( $\mathrm{s}$ híbkovou eróziou od niekolko stoviek do $2000 \mathrm{~m}$ a viac), strmými svahmi, hojným výskytom skál a sutín, ostrými hrebeňmi, formami reliéfu starého a súčasného zaladnenia, fyzikálnym, mrazovým zvetrávaním. Obdobná charakteristika sa uvádza aj v hesle „alpinský reliéf“s poznámkou, že v polárnych oblastiach, kde sa snežná čiara znižuje, uvedený typ reliéfu prináleží aj stredne vysokým a nízkym pohoriam. $Z$ toho logicky vyplýva, že pre vymedzenie stredne vysokých a nízkych pohorí v polárnych oblastiach nie je rozhodujúci reliéf, ale asi nadmorská výška (iné kritériá sa neuvádzajú).

Pre stredohorský reliéf, resp. stredne vysoké pohoria je charakteristické relatívne prevýšenie 500-2000 m, mäkko modelované hrebene, okrúhle vrchy, pomerne 
mierne svahy, pri modelácii reliéfu sa uplatñujú erózne procesy ako hlavné. Ako príklady sa uvádzajú Karpaty, Stredný Ural a Apalačské pohorie. Nesiahajú po snežnú čiaru a nemajú glaciálny reliéf. Niekde majú vysoké plošiny (Pamír, Tibetská plošina), pre ktoré je charakteristický ladovcový reliéf. $\mathrm{V}$ polárnych oblastiach sa však vyznačujú alpínskym a ladovicovým reliéfom, čo platí aj pre nízke pohoria. Nejdeme sa zaoberat charakteristikou nízkych pohorí, nízkohorského reliéfu. Upútala nás však poznámka, ku ktorej sa ešte vrátime, že ak ich relatívne výšky nie sú značné, môžu predstavovat nižši pás pomerne nevysokých chrbtov dvíhajúcich sa nad nimi na vysokých plošinách, napr. Pamíra a Tan-šanu, ležiacich vo výškach 3000 až $4000 \mathrm{~m}$.

$\mathrm{Z}$ názvu hesiel, v ktorom sa nerozlišuje obsah napr. pre vysokohorský reliéf a vysoké pohorie, by vyplývalo, že reliéf patrí (okrem výšky) k rozhodujúcim kritériám pre vyčlenenie vysokých pohorí. Ak však vysokohorský reliéf je charakteristický aj pre určité stredne vysoké a nízke pohoria, to degraduje jeho diferenciačnú funkciu pre odlišenie základných kategórií horských území. Informácie o ostatných krajinných zložkách pri charakteristike vysokých pohorí v spomenutej encyklopédii vcelku chýbajú, alebo sú len velmi skromné a nestačia na vytvorenie kompletného obrazu o vysokohorskej krajine. Viac údajov o krajinných elementoch okrem reliéfu, nájdeme pod heslom ,,alpínsky“, príp. „,subalpínsky“ (ide o stupeň a porasty - ,,alpínske a subalpínske lúky“").

$Z$ informácí́ v sovietskej geografickej encyklopédii nie je jasné, aké hlavné, rozhodujúce kritérium platí pre rozdelenie pohorí do troch spomenutých kategórií. Ak chceme niečo rozdelit, musíme jasne stanovit, podla čoho budeme triedit, ako budeme postupovat. Môžeme použit aj viac kritérií, ale na rôznych úrovniach tak, aby členenie malo svoj systém. Hlavné kritérium rozdeluje objekt na hlavné časti, ktoré môžeme đalej členit podla iného kritéria. Takto odkryjeme $\mathrm{v}$ skúmanom objekte (napr. v určitom výseku zemského povrchu) jeho logickú štruktúru. Použitie viacerých deliacich kritérií na jednej systémovej úrovni vnáša do členenia chaos, čo môôže viesṫ až k nezrozumitelnej terminológii.

Porovnajme niektoré údaje zo sovietskej encyklopédie. Karpaty sú zaradené do stredne vysokých pohorí. Dosahujú Gerlachovským štítom $2655 \mathrm{~m}$. Ich najvyššia čast', Vysoké Tatry, majú podla nášho názoru jednoznačne vysokohorský ráz. V tomto hesle (,stredohorský reliéf, stredne vysoké pohorie“) sa hovorí, že pohoria tejto kategórie niekde majú vysoké plošiny s glaciálnym reliéfom, pričom ako príklad je uvedený aj Pamír. Časti plošinatých pohorí Pamíru, Ťan-šana vo výškach 3000-4000 m, ak ich relatívne výšky nie sú značné, sú zaradené dokonca do nízkych pohorí. $Z$ uvedeného vyplýva, že $\mathrm{v}$ tomto prípade hlavným kritériom je relatívna výška či vertikálna členitost. V prípade začlenenia Karpát ako celku by sa dalo súhlasit. V prípade Pamíru musíme postupovat podla toho istého princípu ako u Karpát, musíme posúdit charakter celého pohoria, nielen jeho časti, určitých jeho orografických jednotiek, vyčlenených $\mathrm{v}$ rámci pohoria. Musíme vychádzat $\mathrm{z}$ charakteru celého pohoria ako základnej územnej jednotky (pozri dalej). Pamír je typickým vysokým pohorím, čo sa prejavuje vysokohorským rázom súboru krajinných zložiek, v ktorom sa diferenciačná funkcia relatívnej výšky a vertikálnej disekcie reliéfu na plošinách stráca $\mathrm{z}$ hladiska posúdenia globálneho charakteru celého pohoria a jeho začlenenia do príslušnej kategórie pohorí.

Nenašli sme zdôvodnenie limitných výškových hraníc, ani absolútnych ani relatívnych výšok, podla ktorých sú vyčlenené spomenuté tri kategórie pohorí. Ak reliéf je tak významným rysom, rozlišovacím znakom $\mathrm{v}$ pohoriach, že vtláča svoju pečat pohoriu a znaky určitého reliéfu platia pre určitú kategóriu pohoria (vysokohorský reliéf pre vysoké pohoria), prečo pohoria vo vysokých zemepisných š́rkach s vý- 
razným glaciálnym reliéfom a všetkými typickými vysokohorskými procesmi sú začlenené do kategórie stredne vysokých až nízkych pohorí? Chápeme, že v encyklopedických heslách niet miesta pre širšie objasňovanie a zdôvodňovanie javov. Ich stručné, heslovité formulácie majú však vychádzat z teoretických, vedeckou verejnostou uznaných prác. Nestretli sme sa s publikáciami, ktoré korešpondujú s encyklopedickými informáciami o uvedených kategóriách pohorí. Ak aj ide v heslách o pôvodné poznatky, musia byt stavané tak, aby sa $\mathrm{z}$ nich dala stanovit koncepcia a kritériá (vrátane ich systému), podla ktorých sú pohoria rozdelené do uvedených kategórií. Reliéf je len jednou, aj ked' velmi dôležitou krajinnou zložkou $\mathrm{z}$ hladiska celkového charakteru pohoria. Pre vyhraničenie vysokohorskej krajiny, pre začlenenie územia $\mathrm{k}$ vysokým pohoriam musíme brat do úvahy aj ostatné krajinné elementy a stanovit mieru ich podielu na vysokohorskom krajinnom ráze.

\section{Vysoké pohoria $\mathrm{z}$ hladiska krajinných typov}

Vysokohorskou problematikou sa najviac zaoberal a najhlbšie ju rozpracoval C. Troll (12 a inde). Opiera sa o krajinno-ekologickú koncepciu. Pre charakteristiku vysokohorskej krajiny a jej vymedzenie považuje tri kritériá ako najdôležitejšie: hornú hranicu lesa ako prejav súčasných klimatických a vegetačných pomerov, pleistocénnu snehovú čiaru ako výraz foriem reliéfu, ktorý vznikol v ladovej dobe, udržal sa dodnes a prevláda vo vysokom pohorí a napokon subniválna alebo periglaciálna hranica odnosu materiálu ako prejav súčasnej pôdnej a geomorfologickej dynamiky (Troll 12, s. 134).

$\mathrm{Na}$ rozdiel od autorov $\mathrm{v}$ sovietskej encyklopédii (4) Troll nelimituje vysokohorskú krajinu absolútnymi výškami a nadmorskej ani relatívnej výške neprikladá osobitný význam pri vymedzovaní jej hranice. Uvádza (4, s. 133), že na nejakom vulkanickom kuželi na Jave tropický les vystupuje až na jeho vrchol do výšky $3000 \mathrm{~m}$, bez toho, že ide o vysoké pohorie. Naproti tomu na Špicberkoch stačí málo stoviek metrov nad morom, aby sme sa ocitli v plne vyvinutej vysokohorskej krajine.

Viacerí autori (in Troll, 4) sa snažili už dávnèjšie vymedzif vysokohorskú krajinu, resp. jej javy. N. Krebs (6) na príklade južného Nemecka považoval pohoria s reliéfovou energiou do $1000 \mathrm{~m}$ za stredohorie, s ešte vyššou energiou za vysokohorský reliéf. Podla švajčiarskeho konverzačného lexikóna (in Troll 4, s. 133) vysoké pohorie musí mat relatívnu výšku aspoň $1500 \mathrm{~m}$. Finch a Trewartha (2),,sierran mountains“", ktoré odpovedajú vysokým pohoriam, definujú reliéfovou energiou vyše $1800 \mathrm{~m}$ a okrem nich rozoznávajú ,low mountains, rough mountains a rugged mountains".

PodIa Trolla (4, s. 147) v pohoriach na Zemi sa dajú vyčlenit tri stupne vo vysokohorskej krajine: 1) dolný stupeň so silno vyvinutou vegetačnou pokrývkou na fosilnom (lepšie reliktnom) vysokohorskom reliéfe $z$ ladovej doby, 2) stredný stupeň so skalami a sutinami a len s malými ostrovčekmi vegetácie, so silnejším mrazovým zvetrávaním a odnosom materiálu volnou soliflukciou, 3) najvyšši niveálny stupeň so stálou pokrývkou snehu a firnu.

Vysokohorské javy, vyčlenené podla troch Trollom uvedených kritérií sú pre vysokohorskú krajinu charakteristické, avšak hranice ich rozšírenia javia rôzne velké odchýlky, obyčajne zvýraznené klimatickỷmi pomerami podnebných pásem. Ohraničenie vysokohorského územia je velmi zložité a zatial iba velmi približné. Aj Troll (12, s. 145) konštatuje, že pri ohraničení vysokohorskej časti pohoria ide o hraničný pás územia a nie o exaktné hraničné čiary. Referuje o výskyte vysokohorských javov a ich odlišnostiach $\mathrm{v}$ rôznych zemepisných šírkach. Zhodnotením jednotlivých vysokohorských javov, ich priestorového usporiadania a vztahu k ostat- 
ným krajinným zložkám, najmä však stanovením ich vymedzovacej hodnoty, ich hierarchickým usporiadaním $\mathrm{z}$ hladiska funkcie pri vymedzovaní je možné hodne upresnif ohraničenie vysokohorského územia. Z tohto hladiska sa chceme vyjadrit k viacerým vysokohorským javcm.

Bezlesie je základným znakom vysokohorskej krajiny. Preto horná hranica lesa môže byt dôležitým hraničným javom vo vysokých pohoriach, nie však vždy. Spoločným menovatelom pre rozš́renie značnej časti vysokohorských javov sú teplotné pomery. V suchých oblastiach rozvoj lesa môže byt limitovaný aj v smere nahor nedostatkom vlahy, takže horná hranica lesa obyčajne nedosahuje nadmorské výšky, do ktorých by mohol les vystúpit $\mathrm{z}$ teplotných dôvodov. V pohoriach najmä subtropického pásma, sčasti ovplyvnených vlahonosnými vetrami, horná hranica lesa často vystupuje na severných svahoch aj o viac stoviek metrov vyššie než na južných. V extrémne suchých oblastiach lesný vertikálny pás môže chýbat alebo existovat v rôznych výškach, kde zasahujú vetry, prinášajúce dostatok vlahy, ako je tomu na západnom úbočí Kordiller nad púštou Atacama (Koepke, 5).

Horná hranica lesa najlepšie indikuje okraj vysokohorskej krajiny $\mathrm{v}$ oblastiach, kde rozvoj lesa v smere nahor limitujú teplotné pomery. Avšak aj tu môže lesnú hranicu znížit vietor a nepriaznivé edafické podmienky. Nevýhodou pri využití hornej hranice lesa ako hraničného znaku sú odlišné ekologické, najmä teplotné nároky jednotlivých drevín, ktoré tvoria lesnú hranicu. Napr. na hornej hranici lesa v strednom Mexiku, ktorú tvorí Pinus hartwegii a kde dosahuje výšku okolo 4000 m,

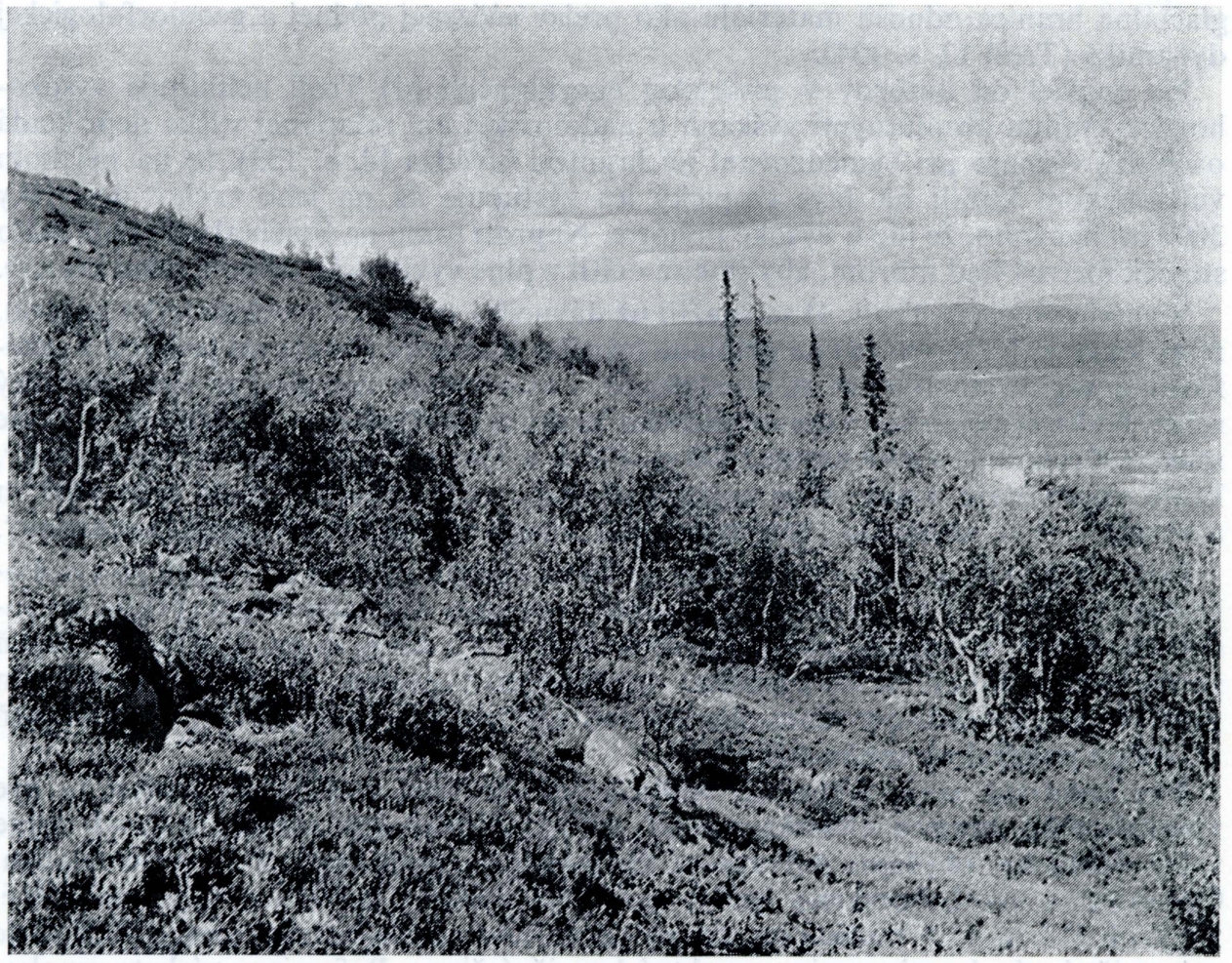

Obr. 1 - Horná hranica lesa v oblasti Gällivare (sev. Švédsko). Tvoria ju brezové porasty so skupinkami smreka. 
na Pico de Orizaba priemerná teplota vzduchu augusta je $7{ }^{\circ} \mathrm{C}$, priemerná ročná teplota $5^{\circ} \mathrm{C}$ (Lauer, 7, s. 94). Naproti tomu priemerná júlová teplota vzduchu vo Vysokých Tatrách na klimatickej (tepelnej) hranici smrekového lesa (Picea abies) vo výške okolo $1700 \mathrm{~m}$ je málo nad $10^{\circ} \mathrm{C}$ (Plesník, 9). Aj ked porovnávané lokality sa vzájomne hodne líšia intenzitou priameho slnečného žiarenia následkom rozdielnych zemepisných šírok, ročným chodom teplôt, snehovou pokrývkou a s ňou súvisiacimi teplotami pôdy atd'., predsa limitujúce teploty uvedených lesných drevín sú príliš velké. Velké ekologické rozdiely drevín na lesných hraniciach sa ukazujú pri porovnaní miernych a subpolárnych šírok medzi severnou a južnou pologulou. Napr. priebeh arktickej hranice lesa sa zhruba kryje s júlovou izotermou vzduchu $10^{\circ}$ (Fries, 3, Pohle, 10 a další). Naproti tomu v oblasti antarktickej hranice lesa dreviny majú tak odlišné teplotné nároky, že ich tažko porovnávat so severnou pologulou. Malý, Tudskou činnostou takmer nedotknutý ostrov Gough Island v južnom Atlantiku $\left(40^{\circ} 19^{\prime}\right.$ j. š. $)$ nemá stromovú vegetáciu, hoci priemerná ročná teplota vzduchu dosahuje $11,7^{\circ}$ (Walter, 13) a mesačné teploty kolíšu medzi $10^{\circ}$ až $14^{\circ}$ (Birot, 1).

Charakteristickým rysom vysokých pohorí je obyčajne velmi rozčlenený, skalný až bralný reliéf so strmými svahmi (obr. 2). Najmä $v$ mimotropických oblastiach hlavný podiel na jeho vzniku má pleistocénne zaladnenie, aj ked’sa zistilo, že v la-

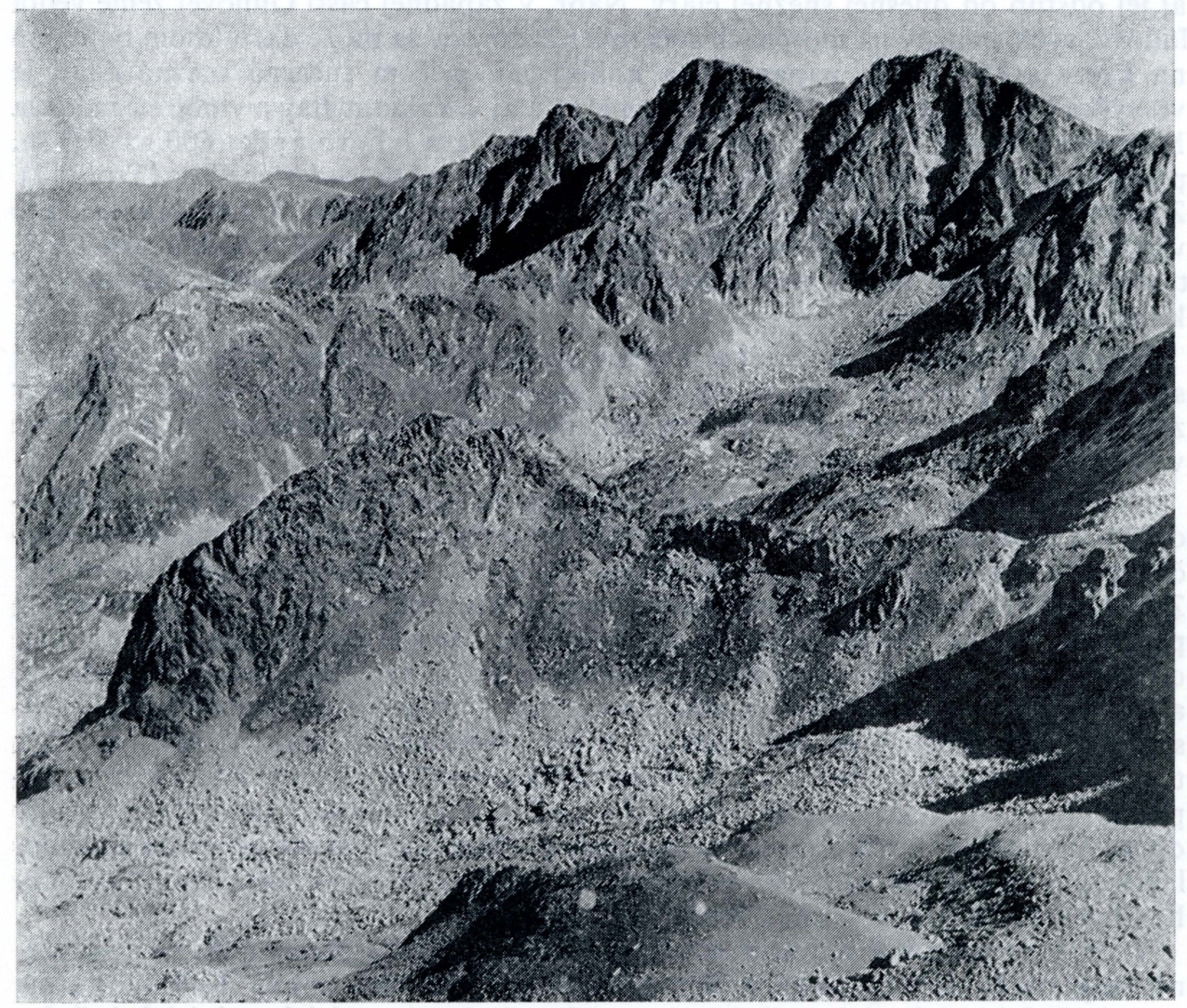

Obr. 2 - Reliktný glaciálny reliéf. Oblast Epčik (západná polovica Kavkazu). 
dovej dobe bolo všade na Zemi väčšie zaladnenie ako je dnešné. Troll (12, s. 138 až 139) uvádza, že v Alpách prebiehala pleistocénna snežná čiara asi o $1200 \mathrm{~m}$ nižšie než dnes, $v$ iných častiach Zeme je tento rozdiel sčasti väčší, sčasti menší. Porovnáva jej priebeh s dnešnou hornou hranicou lesa $v$ rôznych pohoriach. $V$ južnom Nórsku vo vonkajšej oblasti fjordov snežná čiara $z$ poslednej ladovej doby má výšku asi $500 \mathrm{~m}$.n. m., kým lesná hranica len asi $400 \mathrm{~m}$. V Alpách pleistocénna snežná čiara na severnom okraji pohoria bola vo výške $1250 \mathrm{~m}$, na východnom vystúpila do $1750 \mathrm{~m}$, na južnom do 1500 . Dnešná hranica lesa má obdobný priebeh, leží však o 100 až 300 m vyššie. Podobne je to aj v Pyrenejách (Troll 12, s. 139). V Sierra Nevada obidve hranice sú v rovnakej výške $(2400$ až $2500 \mathrm{~m})$, blízke hodnoty dosahujú aj na Balkánskom poloostrove a takmer rovnaké na Urale, v Malej Ázii sa líšia asi o 100 až $200 \mathrm{~m}$.

Aj v pohoriach Severnej Ameriky na rôznych miestach (White Mountains, Cólorado Rocky Mountains, Mexico, Sierra Nevada, Troll, 12) zistil, že dolná hranilea karov sa nepretržite kryje s hornou hranicou lesa. Naproti tomu v suchších trópoch a subtrópoch obidve porovnávané hranice vystupujú velmi vysoko. Úbytok vlahy sa však viac prejavuje na výške snežnej čiary, ktorá rýchlejšie stúpa ako horná hranica lesa, takže ich výškový odstup sa zväčšuje. V oceánskych oblastiach s vysokým ročným úhrnom zrážok snežná čiara sa výrazne znižuje, narastajú ladovce, ktorých splazy môžu hlboko siahat pod súčasnú hranicu lesa, pričom sa zmenšuje aj jej odstup od dnešnej snežnej čiary. Napr. v západnej časti Ohňovej zeme vedla ladovcových splazov na morénach súčasných ladovcov sa mûže darit lesom bohatým na kvety a obývanych papagájmi a kolibríkmi, pričcm súčasná snežná čiara je vo výške lev 400 až 600 m. Podobné pomery sú aj v Yakutat-Bay a v oblasti ladovca Màlaspina v južnej Aljašše, kde dnešná snežná čiara leží vo výške 600 až $800 \mathrm{~m}$, pričom na rozlahtých morénach \adovica Malaspina môžu rást bujné lesy (Troll, 12). $Z$ uvedenélio vyplyva, ze aj hranicu reliktného glaciálneho reliéfu, velmi typického pre vysokohorskú krajinu, jej funkčnú hodnotu pri vymedzovaní vysokého pohoria, treba diferencovat najmä podla podnebných pásem a $\mathrm{v}$ rámci nich podra makroklimatických pomerov.

Významný znak vysokohorskej krajiny predstavuje skupina javov, ktorá súvisí s teplotnými pomermi. Ide najmä o striedanie nižších a vyšších teplôt, o účinky zamf́zania a rozmŕzania povrchu, nepokrytého snehovou pokrývkou, predovšetkým $\mathrm{v}$ súčinnosti s vodou a vetrom.

Chladné a hodne vlhké prostredie velmi spomaluje činnost organizmov, rozkladajúcich biomasu. Odumreté zvyšky rastlín následkom pomalej humifikácie sa obyčajne hromadia ako kyslý, surový humus. Rastlinré zvyšky sa časom rozdrobujú. Zmiešavajú sa $\mathrm{s}$ anorganickými substanciami, s ktorými vytvárajú zmes bez pevnej pôdnej štruktúry. Takáto masa po premočení sa neudrží pohromade ani na svahu o malom sklone a tečie (soliflukcia). Soliflukcia je síce typickým javom $\mathrm{v}$ tundrovej a vysokohorskej zóne, môže sa však vyskytovat aj mimo nich, najmä $v$ ich susedstve, kde pôda nemá pevnú štruktúru a po premočení sa stáva kašovitou. Tlak takejto masy môže vychylovat kmene mladých stromčekov zo zvislého smeru a zapríčinit fajkovité zakrivenie bázy kmeňa, najmä v oblasti hornej hranice lesa. Vysoký obsah mechanicky rozdrobených rastlinných zvyškov síce výrazne prispieva k vzniku labilnej kašovitej pôdnej zmesi, avšak soliflukčné javy pri vymedzení hraníc vysokohorských krajín treba velmi diferencovat.

V náveterných polohách na miestach, kde je vegetačná a pôdna pokrývka narušená, nepremokrené organické zvyšky a jemné anorganické, najmä ílové substancie sa stávajú lahkou koristou silných vetrov, ktoré sú vo vysokých polohách bežným javom. Súčinnostou zamŕzania, soliflukcie, vetra a vody vznikajú rôzne povrchové 
formy, bežne označované ako „pôdy“ (polygonálne, girlandové a dalšie). Tieto javy nemožno označit ako pôdy, pretože ide o geomorfologické útvary.*)

Voda, ktorá sa kapilárne dvíha $\mathrm{k}$ povrchu, zamŕza vo forme ihlicového ladu. Ak sa nad ním rozprestiera plocha nejakého pevného kompaktného telesa (napr. štrku), dvíha ho, ak nie je príliš tažké. Mráz takýmto spôsobom vytláča skelet z pôdy na jej povrch, roztrieduje materiál. Častým zamízaním a rozmízaním vznikajú polygonálne, pásové a iné pôdy, ktoré sa označujú ako štruktúrne (Troll, 11). Ich rozsah súvisí s híbkou premŕzania povrchu. Ich drobné formy nachádzame v tropických pohoriach, kde po celý rok v noci mrzne a vo dne plytko zamrznutý povirch rozmŕza. Pekne vyvinuté polygonálne pôdy o priemere okolo $10-20 \mathrm{~cm}$ sme našli na Kilimandžáre nad sedlom medzi Kibo a Mawenzi vo výškach asi $4600-4800 \mathrm{~m}$. S pribúdaním intenzity mrazov sa ich priemer zväčšuje. V miernych a vysokých zemepisných šírkach polygonálne pôdy sa formujú najmä $v$ období, kedy teploty kolíšu okolo $0^{\circ} \mathrm{C}$, na miestach nepokrytých snehom. Tieto základné podmienky sa menia s nadmorskou výškou a s časom v priebehu roka. Najvhodnejšie podmienky $\mathrm{v}$ nižších vysokohorských polohách sú na prechode leta a zimy, kedy snehová pokrývka chýba, alebo je natolko slabá, že na výslnných miestach $v$ ešte dost teplom dni sa sneh roztopí, takže $v$ ncci môže pôda zamrznút. Následkom transportnej činnosti vetra ako aj rozdielnej orientácie svahov voči slnku snehová pokrývka máva nerovnakú hrúbku. Preto vo vyšších polohách na plochách, kde sneh ustúpi až v lete, kedy sú nočné mrazy slabé, môžu vzniknút drobné formy polygonálnych pôd aj v mimotropických pohoriach. Velkost a nadmorská

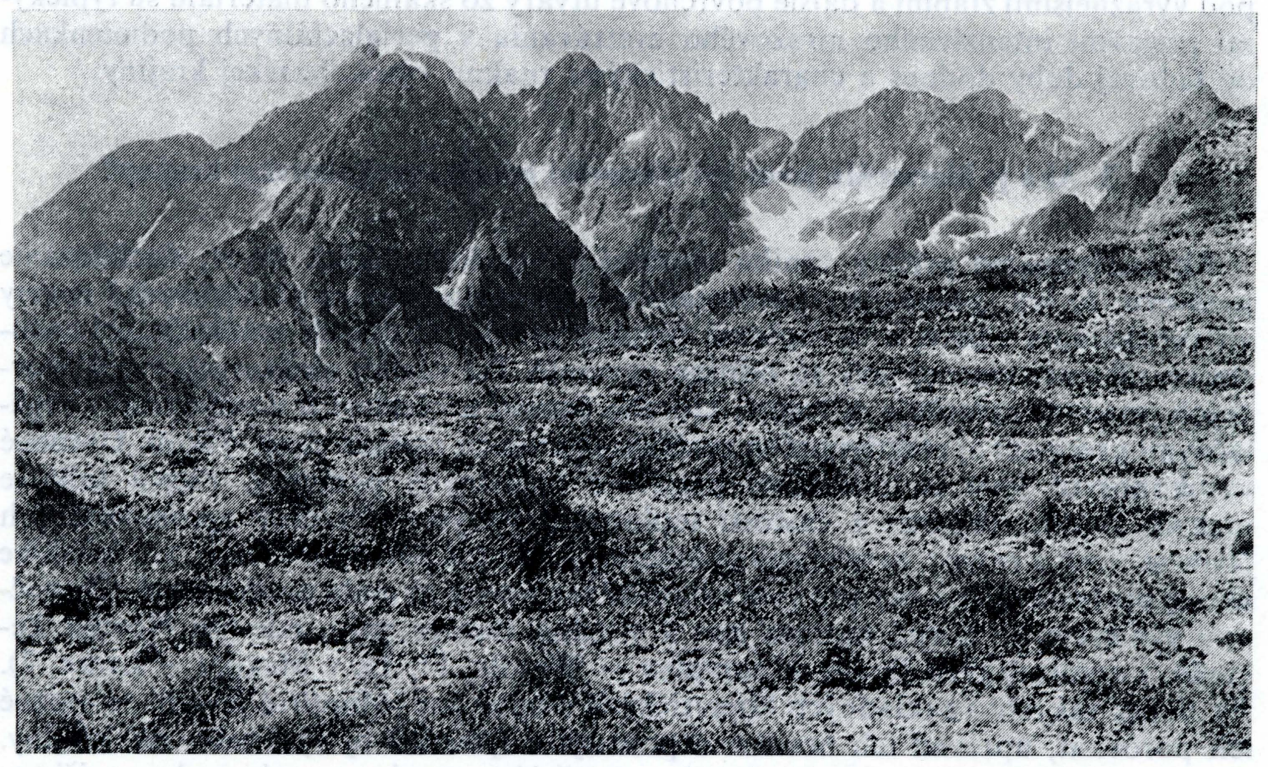

Obr. 3 - Dlhé formy girlandových ,pôd“ vo vrcholovej časti Belianskych Tatier (Západné Karpaty). Autor fotografií P. Plesník.

*) Proto jsou správné termíny „kamenné polygony“, ,,půdní girlandy“, „,kamenné pruhy“ a „kamenné věnce“ - viz J. Rubín a kol.: Atlas skalních, zemních a pủdních tvarủ. Academia, Praha 1986. - Pozn. recenzenta. 
výška týchto javov varírujú podla miestnych podmienok usmernených podla makroklimatických pomerov.

$\mathrm{Na}$ miestach, kde je sneh $\mathrm{v}$ zime sfukovaný, takže pôda je vystavená dlhs̀ie trvajúcemu zamízaniu a rozmízaniu ako aj na výslnných svahoch, kde snehová pokrývka rýchlo ustúpi, vo vysokých polohách napr. stredoeurópskych pohorí sa často vyskytujú rôzne formy girlandových pôd (obr. 3). Na ich vzniku, okrem regelačných procesov (zamŕzania a rozmízania) sa zúčastňuje vietor, soliflukcia, príp. aj zrážková voda. V Belianskych Tatrách (Západné Karpaty) sú rozšírené najmä v hrebeňovej oblasti vo výškach $1900-2000 \mathrm{~m}$, nachádzame ich však aj hodne nižšie v silno náveterných polohách, aj v kosodrevinovom stupni (asi v 1750-1800 m), avšak na miestach, kde pastieri odstránili kosodrevinové (Pinus mugo ssp. pumilio) kroviny (Plesník, 8).

Typickým javom pre vysokohorskú krajinu je aj množstvo až suverénna prevaha holých skál, sutín, nakopených balvanov rôznej velkosti a dalších útvarov s nedostatkom jemnozeme. Sú výsledkom súčasného ako aj niekdajšieho najmä pleistocénneho zvetrávania skalného podkladu. Velké objemové zmeny ako následok kolísania teplôt vplyvom riedkeho vzduchu a tým intenzívnej insolácie a vyžiarovania, zamŕzanie vody $v$ puklinách a ich roztahovanie ladom spôsobuje pomerne rýchlu deštrukciu skalného podkladu mechanickým rozpadom. Niekdajšie štíty, ktoré sa rozpadli na hŕby skál a balvanov, rozpadnuté skalné nerovnosti a výčnelky na svahoch, $\mathrm{z}$ ktorých vznikli rozsiable blokoviská na periglaciálne modelovaných a tým aj hladkých svahoch, mohutné úsypy pod skalnými stenami, ktoré vznikli odtatím ladovcov posledného glaciálu, murovo-sutinové kužele pod výraznejšími žlabmi a dalšie povrchové útvary zo skalného materiálu sú typickými prejavmi intenzívneho mrazového zvetrávania $\mathrm{v}$ periglaciálnych podmienkach od Padovej doby dodnes a charakteristickými znakmi vysokohorskej krajiny.

\section{Aká je hierarchia javov pri stanovení hraníc vysokohorskej krajiny?}

Ak analyzujeme príčiny vzniku uvedených vysokohorských javov, dochádzame $\mathrm{k}$ záveru, že ich spoločným menovatelom $\mathrm{v}$ podstatnej miere sú klimatické zmeny vo vertikálnom smere, a to teplotné pomery pri dostačujúcich zrážkach, pri nedostatku vlhkosti viaceré javy sú odlišne vyvinuté. Pri vzniku niektorých vysokohorských javov sa uplatňuje aj vietor, ktorého častost a rýchlost' a v súčinnosti s regelačnými procesmi aj efektívnost sa zväčšuje s rastúcou nadmorskou výškou. Uvedené vysokohorské javy sú odrazom, prejavom teplotných pomerov, najmä celkove nízkych teplôt, velkosti a častosti teplotných výkyvov. Procesy vysokohorských javov sú vcelku známe, avšak limitné hodnoty, teplotné parametre javov, ich iniciálne ako aj optimálne hodnoty pre vysokohorské fenomény sú málo preskúmané. Čiastočnou výnimkou je horná hranica lesa $v$ strednej Európe, príp. inde (na Novom Zelande, v coloradských Rocky Mountains - Wardle, 14, 15, v Mexiku - Lauer, 7). Po zistení takýchto základných klimatických údajov pre jednotlivé javy bude možné ich porovnat, upresnif ich hranice a presnejšie vymedzit aj vysokohorské krajiny. Teploty sa celkove pomaly a plynule zmenšujú $s$ rastúcou nadmorskou výškou, avšak ich denný a ročný režim a kolísanie, sezónnost, ktoré podstatne ovplyvňujú viaceré vysokohorské javy, sú v rôznych zemepisných šírkach tak rozdielne vyvinuté, že jednotlivé javy treba skúmat a hodnotit podla klimatických pásem.

Vegetačná pokrývka je základnou krajinnou zložkou. Krajinné procesy prebiehajú odlišne od procesov v nelesnej krajine, pričom les sa vo velkej miere zúčastňuje na týchto rozdieloch. Komplexy lesných porastov si vytvárajú svoju vlastnú fyto- 
klímu, ktorá sa vyznačuje menšími teplotnými a obyčajne aj vlhkostnými výkyvmi. Tlmia intenzitu priameho žiarenia a ncčného vyžiarovania. Ide o klimatický rys, ktorý je v rozpore s vývojom periglaciálnych javov, charakteristických pre vysokohorskú krajinu. Efekt tohto protikladu je ešte zvýraznený riedkym vzduchom vo velkých výškach. Na hornej hranici lesa sa menia viaceré klimatické prvky. Okrem uż spomenutých dochádza $\mathrm{k}$ zmene najmä veterných, niekde aj vlhkostných pomerov a v mimotropických pohoriach aj snehovej pokrývky. Plynulé vertikálne zmeny klimatických prvkov na prechode lesa do bezlesia dostávajú výraznejší, strmší spád. Lesný porast svojským spôsobom ovplyvňuje geomorfologické prccesy (znemožňuje veternú a zmenšuje výmolovú eróziu, zmierňuje regelačné prccesy a celkove spomaluje odnos materiálu), pcdzemné a povrchové vodstvo (najmä povrchový odtok, zasakovanie a hospodárenie s podzemnou vcdou). Les sa líši cd nelesných vysokohorských plôch obyčajne aj pôdnymi typmi, najmä však inventárcm svojráznych rastlinných a živočišnych druhov, vyznačujúcich sa špecifickỷmi znakmi, vyplývajúcimi $\mathrm{z}$ prispôsobenia sa osobitným vysokohorským podmienkam. Tak je tomu $\mathrm{v}$ stredoeurópskych pohoriach, kde nad lesnou hranicou začína celkom iný organický svet. Nie je tomu tak všade na zemskom povrchu.

Les teda má vysokú diferenciačnú hodnotu v krajine, pretcǒe ovplyvňuje značnú čast jej zložiek. V' žiadnom prípade ho n€možno začleňovat do vysckohor k€j krajiny. V oblastiach, kde rozvoj lesa s rastúcou nadmorskou výškou limituje nedcstatck vlahy, funkcia lesa pri vyhraničení vysokohorskej krajiny sa stráca. Kam položit jej hranicu v pohoriach extrémne suchých oblastí? Dá sa predpokladat, že teplotné zmeny, výška a režim denných či nočných teplôt aj tu dávajú určitý tón krajinným procesom. Uplatňujú sa procesy zamŕzania a rozmŕzania, mrazového zvetrávania, rastliny a živočíchy tu majú iné ekologické nároky ako v nižších polohách. Prechcdy spoločenstiev sú plynulejšie a výraznostou sa nedajú porovnávat's lesnou hraniccu, jednako však v určitých výškach na základe cdlišných ekologických vztałov nadobúdajú vysokohorský charakter, čo sa odráža aj v ich floristickom zložení. Hranicu medzi nimi a nižšie ležiacimi formáciami, spolu s hranicou výšky periglaciálnych procesov a javov a najmä na základe analýzy teplotných pomerov možno brat ako hranicu vysokohorskej krajiny v suchých bezlesných oblastiach.

Stanovenie hranice vysokohorskej krajiny má mat hierarchický postup. Treba vychádzat $\mathrm{z}$ teplotných pomerov a ich dopadu na krajinné zložky, na ich účast v krajinných procesoch a javoch. Nie všetky vysokohorské fenomény cdzrkadlujú tieto výškové teplotné pomery rovnakou mierou, a preto treba ich význam pri limitovaní územia citlivo diferencovat'. Po rozšírení a prehíbení poznatkev o klimatických parametroch vysokohorských javov a logickom výbere kritérií bude možné upresnit', zúžit prechodný pás až na čiaru. Je to potrebné pre posúdenie, či vysokohorská krajina zaberá dostatc čne velkú čast v horskom celku, aby tento mohol byt začlenený do kategórie vysokých pohorí.

Reliéf je významnou črtou pre pchoria a spolu s geologickou stavbcu často býva podkladom pre členenie horských úzє mí na menšie orcgrafické celky. S výnimkou glaciálneho, ktorého vznik je úzko spätý s vysokohorskou klímcu, v charaktere vysokohorskej krajiny nemá rozhcdujúci význam. Sú vyscké pohoria, najmä plcšinaté, ktorých značné časti sa vyznačujú slabým vertikálnym rczčlenen'm. Naproti tomu rýchlo sa dvíhajúce pohoria, zložené z hornín s rczdielncu gecmorfclc gickou hodnotou, v ktorých sa stricdajú nad sebou súvrstvia velmi cdolných a súvrstvia mäkkých, málo odolných hornín, môžu nadobudnút velkú reliéfcvú crergiu s hlbokými stiesnenými dolinami, bralnatými hrєbeňmi. Ich reliéf je vert kélre silro rozčlenený a má ovela divokejší ráz než na plcšinách vysckých połorí, hcci malou výškou môžu spadat (podra sovietskej geografickej encyklopédie, 4) aj do kategórie 
nízkych pohorí. Relatívna a ani absolútna výška pohoria teda nie je jednoznačným kritériom pre zaradenie územia do kategórie vysokých alebo nevysokých pohorí.

Ako postupovat pri kategorizácii územia, ak len čast pohoria má vysokohorský charakter? Velká svojráznost vysokohorskej krajiny zapríčiňuje, že do kategórie vysokých pohorí sú zaradené aj také, kde len malá vrcholová čast pohoria má vysokohorský charakter. Nik nepochybuje o tom, že Kilimandžáro, ale aj dalšie hodne nižšie východoafrické vulkány (Meru, Virunga a dalšie), patria do kategórie vysokých pohorí, ako to jednoznačne vyplýva z literatúry, aj ked' vysokohorská krajina v pohorí plošne neprevláda. Podla nášho názoru každý jav či objekt má byt nazvaný podla charakteristického, hlavného znaku, najmä však podla prevládajúceho celkového charakteru objektu. Vo vysokom pohorí by mal prevládat typ vysokohorskej krajiny. S ohladom na doterajšiu hlboko zaužívanú prax začleňovat do vysokých pohorí aj orografické celky, v ktorých vysokohorská krajina zaberá len malú vrcholovú čast', navrhujeme dočasne (kým sa problém nevyrieši definitívne) rozdelit pohoria, doteraz označované ako vysoké na pravé (ak vysokohorská krajina $v$ nich priestorove prevláda) a nepravé vysoké pohoria (ak je v menšine). Za rozhodujúce kritérium považujeme všeobecný, aj ked jednoduchý princíp prevahy (podobne ako u prechodu lesa do nelesných formácií, Plesník, 9) určitého javu. Toto kritérium je exaktné a tým meratelné a má nosnú funkciu.

Ako postupovat pri začleňovaní orografických celkov do vysokých alebo nevysokých pohorí? Aj tu treba vychádzat z celkového charakteru územia, z horského systému ako celku. Rozsiahle pohoria (Himaláje, Tan-šan, Andy, severoamerické Kordillery a dalšie) sa obyčajne skladajú z orografických jednotiek, menších až drobných celkov, ktoré obyčajne patria do nízkych (na okrajoch), stredne vysokých a vysokých (v najvyšších, často centrálnych častiach) pohorí. Takýto horský systém musíme posudzovat ako horský celok, ako územnú jednotku a podla spomenutého kritéria priestorovej prevahy ho začlenit do patričnej kategórie. Nie je myslitelné, aby z hladiska krajinných typov čast plošinatého územia Pamíru vo výškach $3000-4000 \mathrm{~m}$ $\mathrm{n}$. m. na základe malej vertikálnej členitosti bola začlenená $\mathrm{k}$ nízkym pohoriam, resp. k nízkohorskému reliéfu (Geografičeskij enciklopedičeskij slovar, 4, s. 201), hoci v plnej miere odpovedá kritériám vysokohorskej krajiny a Pamír ako celok patrí do kategórie vysokých pohorí. Podla tohoto princípu Karpaty ako celok možno začlenit do nevysokých pohorí. $\mathrm{V}$ ich rámci však treba rozoznávat okrem nízkych a stredne vysokých aj vysoké pohoria (ako orografické celky), a to typické (podla nášho návrhu pravé), akými sú Vysoké Tatry, ako aj početné nepravé(Nízke Tatry, Velká Fatra, Malá Fatra, Munții Rodnei, Munții Apuseni a dalšie).

Snažili sme sa posúdit, doplnit a hierarchizovat princípy pre vymedzenie vysokohorskej krajiny a vysokého pohoria. Rešpektovali sme všeobecne zaužívaný termín „,vysoké pohorie“", aj ked nemáme pritom dobrý pocit. Prívlastok „vysoký“ dáva predstavu o pohorí, že vyniká velkou výškou. Tento atribút podla zmyslu slova by mal byt hlavným princípom triedenia pohorí. Ak by sme $\mathrm{z}$ hladiska krajinných typov vytvorili kategórie pohorí striktne podla výšky, do jednej kategórie sa nám dostane neprehladná zmes krajinných typov od lesných tropických cez savanové, púštové, stepné atd’ až po krajiny večného snehu a ladu. Ako sa dospelo k tejto základnej terminologickej závade? Jej korene väzia $\mathrm{v}$ histórii a $\mathrm{v}$ nesprávnej aplikácii pôvodne správne používaného termínu.

Vysokohorská krajina a jej charakteristické javy dávno upútali záujem bádatelov v Alpách, ktoré tým vošli do širokého povedomia ako vysoké pohorie. Táto skutočnost' sa prejavuje aj v terminológii. Súvisí s ňou aj termín „alpínsky“ a odvodeniny od neho. Snaha všeobecne aplikovat tento model viedla aj $k$ nesprávnej terminológii (napr. časté používanie ,,alpínsky“ v tropických či iných pohoriach ne- 
alpského typu). Pravdepodobne tu má korene aj základné pomenovanie ,,vysoké pohorie" (high mountains, haute montagne, Hochgebirge, vysokie gory atd..) Alpy so svojráznym krajobrazom sa práve výškou líšia od ostatných okolitých pohorí, ktoré nemajú vysokohorské javy, čo sa dalo stručne a priliehavo vyjadrit rozlišovacím termínom „,vysoký“. Tento základný výraz, ktorý v oblasti svojho vzniku je plne opodstatnený, bol jednoznačne aplikovaný na celú Zem, čo naráža na tažkosti. Napr. $\mathrm{v}$ pohoriach polárnych oblastí obsah tohoto základného pomenovania stráca svoj rozlišovací význam, stráca zmysel. Zhruba všetky charakteristické krajinné rysy sa dostávajú do rozporu s obsahom pojmu. Prívlastok „,vysoké“ dezorientuje, zvádza $\mathrm{k}$ omylom, čo treba riešit. Aj nadalej považujem za správne kategorizovat pohoria podla prevahy krajinných typov, z ktorých vysokohorská krajina ako celok, ale aj jej zložky, sa výrazne vynímajú.

\section{Záver}

Vynára sa otázka, ako dalej. Ponechat zaužívaný termín „,vysoké pohorie“ aj napriek jeho základnej terminologickej závade? Hoci znaky pre vysokohorskú krajinu sú dávnejšie známe a všeobecne sa vie, čo sa pod termínom „,vysoké pohorie“" rozumie, dochádza aj v najnovšej literatúre k zásadne odlišným stanoviskám, ktoré sme už rozobrali. Zdá sa, že autori v sovietskej geografickej encyklopédii (4) zdôraznením výšky sa snažili aj korigovat terminologický rozpor medzi pomenovaním a obsahom objektu. Je to jeden $\mathrm{z}$ dôvodov uvažovat o zmene prívlastku,,vysoké" pohorie. Treba hladat taký prívlastok, ktorý by integroval krajobraz doterajšej vysokohorskej krajiny vo všetkých klimatických pásmach, v pohoriach bez ohladu na ich absolútnu či relatívnu výšku.

Skutočnost, že o vysokohorských javoch a procesoch rozhodujú teplotné pomery, nás smeruje hladat výraz v oblasti klimatickej terminológie. Nízke teploty, celkový nedostatok tepla limituje rozvoj lesa a vtláča hlbokú pečat rastlinstvu a živočišstsu. Ovplyvňuje (v kombinácii s ich režimom, kolísaním) geomorfologické a pedogenetické procesy. Zásadne vplýva na režim a teploty povrchových a podzemných vôd. Všetky uvedené znaky jednotlivých krajinných zložiek, ale aj krajiny ako celku sa dajú sústredit pod jednu strechu, ktorou je studená klíma. Preto termín „,studená krajina" svojím obsahom zodpovedá vysokohorskej krajine napriek tomu, že prívlastok ,studený“ má často relatívnu hodnotu, avšak sa dá vymedzit teplotnými parametrami, a to jednoducho a presne, aj vo forme čiary ako hranice. Územie s prevahou studenej krajiny dá sa aplikovat aj na horský celok, takže „,studené“ pohorie by mohlo nahradit doterajš́ zauživaný termín ,vysoké pohorie“. Naviac tento pojem poskytuje priestor aj pre pomenovanie iných krajinných typov (mierna, teplá, horúca krajina). Napokon ide o princíp, ktorý sa už aplikoval, napr. ako „,tierra caliente, tierra templada, tierra fría“ v Južnej Amerike, ,,colla, vojna dega, dega" v Etiópii. Zatial toto predkladáme ako návrh do všeobecnej diskusie.

Pohoria sa však dajú členit, zatriedit do určitých kategórií podla lubovolného kritéria. Dôležitý je však zmysel členenia, podla ktorého treba vybrat aj kritérium pre zatriedenie do kategórií a zdôvodnit jeho vedecký a spoločenský dosah. Pohoria by sa dali začlenit do kategórií aj podla výšky, napr. z hladiska orogenetických procesov, príp. z určitých klimatických aspektov (ako bariéry pre vzdušné prúdy, $z$ hladiska vertikálnej diferenciácie žiarenia), príp. $z$ iných tíčelných dôvodov. Napokon, o pohoriach sa dá hovorit ako o nízkych a vysokých a začlenit ich do kategórií aj z najvšeobecnejšieho hladiska, ako o hocijakom inom objekte (napr. výška 
človeka, stromu a pod.). My sme chceli podat obraz (a zaujat stanovisko) o doteraz všeobecnom chápaní pojmu vysoké pohorie, ktoré sa opiera o charakter vysokohorskej krajiny, vrátane jej zložiek a charakteristických krajirných znakov.

\section{Literatúra:}

1. BIROT, P.: Les formations végétales du globe. Paris $1965,508 \mathrm{~s}$.

2. FINCH, V., TREWARTHA, G. T.: Elements of Geography. New York - Toronto - London 1922.

3. FRIES, Th.: Botanische Untersuchungen im nördlichsten Schweden. Uppsala et Stockholm 1913.

4. Geografičeskij enciklopedičeskij slovar. Moskva, Sov. enciklopedija 1988, 432 s.

5. KOEPKE, H.-W.: Synökologische Studien an der Westseite der peruanischen Anden. Bonner Geogr. Abhandlungen 29, Bonn 1969, 320 s.

6. KREBS, N.: Die Karte der Reliefenergie Süddeutschlands. Peterm. Geogr. Mitteilungen 1922.

7. LAUER, W.: Nekatorije rezultaty sovremennych issledovanij verchnej granicy lesa na vulkanach centralnoj Mexiki. In: Vysokogornaja geoekologija, Inst. geogr. AN SSSR, Moskva 1976, 94-97 s.

8. PLESNÍK, P.: Vplyv vetra na vznik a vývoj niektorých foriem periglaciálnych pôd vo východnej polovici Belanských Tatier. Geogr. čas. VIII, č. 2-3, Bratislava 1956, s. 42-64.

9. PLESNÍK, P.: Horná hranica lesa vo Vysokých a v Belanských Tatrách. Vydav. SAV Bratislava $1971,238 \mathrm{~s}$.

10. POHLE, R.: Wald- und Baumgrenze in Nord-Russland. Zeitschrift der Gesellschaft für Erdkunde zu Berlin. Berlin 1917, 205-229 s.

11. TROLL, C.: Strukturböden, Solifluktion und Frostklimate der Erde. Geol. Rundschau Bd. 34 , Stuttgart $1943 / 44$.

12. TROLL, C.: Ökologische Landschaftvorschung und vergleichende Hochgebirgsvorschung. Erdkundliches Wissen 11, Wiesbaden 1966, $366 \mathrm{~s}$.

13. WALTER, H.: Vegetation der Erde. Bd. 2. Jena 1968, 1001 s.

14. WARDLE, P.: A Comparison of Alpine Timberline in New Zealand and North America. New Zealand Journal of Botany 1965, Vol. 3, No. 2, 113-135 s.

15. WARDLE, P.: An Explanation for Alpine Timberline. New Zealand Journal of Botany 1971, Vol. 9, No. 3, 371-402 s.

Summary

THE TERM "HIGH MOUNTAINS”

In the scientific literature we can see two absolutely different approaches tô the term "high mountains". In the dictionary Geografičeskij enciklopedičeskij slovar (1988) the mountain types are distinguished according to their elevation as high, medium-high and low. Great importance is laid on relief as we can see on the same contain of entries for individual relief - and mountain-types (high-mountain relief, high mountains). It cannot be the final criterion because low mountains in polar regions are characterized by glacial relief, but low-mountains relief has been mentioned from high plateaux of the Pamir and the Tiang Shan Mts. at the elevation 3.000 to $4.000 \mathrm{~m}$.

The other, older conception was elatorated by Troll, who most worked out the problems of high mountains. He started from landscape-tyres, from the landscape-ecological base. For the recognition of high-mountain landscare he considered three signs as most important: the upper timberline relict glacial relief left frcm a glacial period and a group of phenomena including solifluction, freeze-thaw weathering and several geomorphological phenomena ("soils") associated mainly with regelation processes. He does not think the real elevation of mountains is important, because while a volcanic mount 3.000 high at Java is wooded up to the top and bears no high-mountain signs, at Spitzbergen in the altitude of only a few hundred meters above the sea level we would find ourselves in high-mountain country.

The principles set down by Troll are exercised to a different extent. In extremely dry areas 
the upper forest line is lowering or the forest isn't present at all. The snow line here is rising and the bottom relict glacial line as well. So the criterions for setting the limits of high-mountain country should be chosen reasonably. Troll states that high-mountain country must be delimitated not by a line but by a wide belt.

Mountains we can classify according to the purpose we follow. We can classify them according to their absolute height (e.g. in connection with orographical processes, their influence to air-currents, intensity of radiation etc., or generally as an object (like a high man, tree and so on). But we want to distinguish mountain areas by their characteristic landscape features, according to prevailing landscape types. From this point of view the term "high mountains" which has been used up to now is not correct because their height is not decisive and this adjective does not express the real content of their features and misrepresents the meaning of the term. Its origin is in incorrect application of the alpine model for all mountains.

What to do to prevent from another complications? Roughly said, all distinctive sings of high-mountain landscape (in sense of Troll) have one common denominator - temperature conditions. A substantial part of high-mountain phenomena is connected with low temperature and its variations. So hitherto existing term "high-mountain country" can be substituted by the term "cold country". That is nothing new if we take into account terms like "tierra fria" or "dega". The temperature conditions as the main criterion for the classification of some area have the great advantage that they can be measured so that the line of high mountains can be delimitated accordingly. The mountains where the cold type of landscape prevails can be called "cold mountains" and so the unsuitable adjective "high" could be replaced. This contribution should serve as a theme for discussion.

(Adresa autora: Krížna 20,811 07 Bratislava.)

Došlo do redakce 11. 3. 1991

Lektoroval Václav Král 